\title{
Lecturers' Compliance with Quality Assurance Mechanisms in Public Universities in Delta State
}

\author{
Amini-Philips Chinyere, PhD \\ Omodibo Eguono E., \\ Department of Educational Management, Faculty of Education, \\ University of Port Harcourt, Nigeria
}

Doi:10.19044/esj.2019.v15n25p208 URL:http://dx.doi.org/10.19044/esj.2019.v15n25p208

\begin{abstract}
The study investigated the extent to which lecturers' complied with quality assurance mechanisms in public universities in Delta State. Two objectives, two research questions and two hypotheses guided the study. The descriptive survey research design was adopted. The population of the study consisted of 1,299 lecturers and 6,826 students from the public universities in Delta State. A sample of 260 lecturers and 409 students representing $20 \%$ and $6 \%$ respectively, of the population was obtained using the proportionate random sampling technique. The instrument used for data collection was a researchers' made questionnaire titled “Compliance with Quality Assurance Mechanisms Questionnaire (CQAMQ). The Cronbach Alpha method was used to determine the internal consistency of the items and it yielded a result of 0.76 and 0.97 for A and B respectively. The researchers and two assistants distributed 669 copies of the questionnaire and successfully collected 628 copies of the questionnaire administered. The research questions were analyzed using the mean, standard deviation and rank order statistics, while the hypotheses were tested using z-test at 0.05 level of significance. It was found that lecturers in public universities in Delta State complied with measurement and evaluation of students learning outcome and the use of interactive teaching and learning method in the classroom to a high extent. The findings revealed that lecturers' compliance with measurement and evaluation of students learning outcomes in public universities in Delta State is high. Based on the findings, it was concluded that lecturers complied with the quality assurance mechanisms to a high extent, it was therefore recommended that the university management should formulate a policy that will make lecturers sustain the strategy of assessing the learning outcome of students and organize more lectures and seminars on how lecturers can sustain the strategies in the use of interactive teaching and learning methods in the classroom.
\end{abstract}


Keywords: Compliance, Quality Assurance Mechanisms, Interactive teaching and learning method

\section{Introduction}

Universities all over the world are regarded as centers of learning, training and research. A university is the highest institution of learning in any society. University education according to the United Nations Educational, Scientific and Cultural Organization (UNESCO) cited in Okojie, (2013) is a platform through which knowledge, skills, attitudes and values of humans are developed in order for them to live a fulfilling life. The university was established to provide sound and qualitative products (graduates) who can live in any environment they find themselves. The aim and goals of establishing university education in Nigeria were aptly spelt out by the Federal Government of Nigeria in the National Policy on Education (FRN 2009, p.38) as follows to:

1. Contribute to national development through high level manpower training.

2. Develop and inculcate proper values for the survival of the individual and society.

3. Develop the intellectual capability of individuals to understand and appreciate their local and external environment.

4. Acquire physical, intellectual, technical and professional skills which will enable the individuals to be self-reliant and useful members of the society.

5. Promote and encourage scholarship, entrepreneurship and community service.

6. Promote national and international understanding and interaction.

Furthermore, the document states that the university shall achieve these by intensifying and diversifying its programs for the development of higher level manpower within the context of national needs and requirements of the country.

It is in recognition of this and the significance of establishing university that has prompted the interest of the society, employers of labour and the government on the concept of quality assurance mechanisms employed by universities to ensure that quality products (graduates) are produced in universities.

Public universities are those universities that are owned by the government (federal or state government) and are funded by the government through grants for personnel costs; research funding and capital expenditure (Odebiyi \&Aina, 2009). Ajadi (2010) mentioned that for the past fifteen years 
the Nigerian University Education System has been going through series of reforms to ensure that there is increased access and quality of graduates from universities.

Quality Assurance (QA) is maintaining a desired level of quality in a product. It is aimed at providing customers with the products they expect. Quality assurance refers to the actions, plans, activities, programs and functions undertaken to ensure standard is reached and maintained. Okojie, (2013) stated that QA refers to deliberate, evidence based strategies and processes of satisfying quality expectations. Nzegbulum and Anyaegu (2016) maintained that quality assurance refers to series of planned actions and activities necessary to provide the customer with the product they expect. In the opinion of Ciwar (2005), quality assurance has to do with setting standards for the processes and activities that leads to delivering of graduates by the training institution. While the concept can be defined in several ways, its core definition includes the idea that it involves processes and activities that include program duration, course content, quality of teachers, standard of instructional facilities, the school environment, examination; this entails quality examination items, supervision, moderation of results and grading. Therefore what is presented is the broad concept of Quality Assurance and the varied views of what it exactly is.

Quality assurance mechanisms are the processes, strategies, measures employed or used by the university to ensure that products meet the expectations of quality. In view of this, Enemali and Adah (2015) saw Quality Assurance Mechanism as operational techniques/measures/strategies used in the universities to detect errors resulting from production processes, provide solution and also avoid or minimize issues relating to improvement of standard or stability in production. The quality of university education in Nigeria has come under severe criticism by stakeholders, the government and society. Thus, it has become necessary for the university to ensure quality products are delivered to the society. However, quality can be attained through the efforts of all stakeholders but the university lecturers have been seen as pertinent stakeholders in assuring quality. The university lecturers are the major implementers of the internal mechanisms in assuring quality products. The university lecturer is someone who stands in front of a class and gives an organized talk designed to teach something. The university lecturer holds a position that covers teaching, research and administrative responsibilities and is solely responsible in the implementation of Internal Quality Assurance Mechanisms adopted by the university. Olatunbosun (2007) stated that the adoption and implementation of the Internal Quality Assurance Mechanisms facilitates the actualization of the goals of tertiary education in Nigeria.

The internal QAM implemented by lecturers among others include: Measurement and evaluation of students learning outcomes, the use of 
interactive teaching and learning method in the classroom. Ajayi and Ekundayo (2008) admitted that teachers are responsible for ensuring education quality and compliance to quality assurance strategies is the way to quality.

Compliance means being willing to do what one is asked to do. Compliance means obeying order, rule or request. Compliance with quality assurance mechanism simply means working in accordance with strategies or techniques of quality assurance in order to attain quality and improve standard. Lecturers' compliance with QAM means lecturers adhering to stated policies, strategies, techniques that are operational in the university to bring about quality in products (graduates).

Students and lecturers need to be assessed regularly to identify any lapses in the teaching-learning process and provide solution as well as identify change in behavior. Evaluation of students learning is very vital in assuring quality in universities. Students learning outcomes are assessed using various techniques depending on what is being assessed. Assessment begins at the admission point or entry point using the JAMB and Post UTME aptitude test to scrutinize and select the best students to be admitted into the university and ends at the final stage of degree examination (Dimson, 2007). According to Ayogu in Dimson (2007), assessment helps to monitor students learning progress, determine the quantity and quality of their learning and screen them at each stage. Howsam cited in Emetarom (2007, p.320) stated that "evaluation involves judging something which we know measures up to what we expect of it". Evaluation is the qualitative judgment which results from assessment based on quantitative data from the tools of testing and measurement. Furthermore, he stated that student courses and performances are assessed using the following forms: end of the course (semester examination), assignment, and term paper, projects, test and degree examination. This is in line with the policy of education (6-3-3-4) which demands that graduates should be produced not only using the cognitive domain but also in the affective and psychomotor domains. Evaluation in teaching is a process of collecting, analyzing and interpreting information about teaching and learning to make informed decisions that enhances student achievement and the success of educational programs (Jabbarifar, 2009). Assessment plays an important role in shaping students way of thinking towards their learning, measurement and evaluation of students learning and academic performances are two inseparable elements in higher education. Summative assessment is the type of assessment employed in many universities. This type of assessment allows the instructor to gauge students' proficiencies in several courses, summative assessment methods like written exams, projects, presentations, and quizzes in order to have a comprehensive understanding of students' learning process (Malapati \& Murthy, 2013). Besides, students have the opportunity of improving their skills throughout the course duration. 
Pertaining to continuous assessment in line with the policy, with respect to the university's peculiarities, C.A. scores should range between $30 \%$ and $40 \%$; this is then added to the end of semester examination which is rated $70 \%$ or $60 \%$ as adopted by the various universities. However, there are various unscrupulous practices as being described between lecturers and students, giving it certain names such as sorting, gratification, pay pass etc. (Mbakwem \& Okeke, 2007). Ajuonuma (2007) maintained that evaluation of students learning experiences in Nigerian universities is made up of continuous assessment and end of semester examination in the three (3) educational domains which account for $30 \%$ continuous assessment and $70 \%$ examination respectively. Akpotu and Ikpesu (2014) said that measurement and evaluation of students learning helps to strengthen the certification process of graduates from universities. Ofejebe, Nwogbo and Anachuna (2015) mentioned that Evaluation of students learning experience at the university level stems from the fact that it is an indispensible tool for determining educational outcome for the purpose of maintenance of standard, promotion, certification, placement, improvement, increased productivity, accountability, quality control among others. There is need for evaluation of students learning outcomes in order to assure quality in university. The design and the practice of instructional evaluation have a great influence on the advancement of academic programs and the performance evaluation of students (Malapati \& Murthy, 2013). Imprecise assessment leads to unproductive results, whereas good quality assessment allows instructors to achieve the course outcome. It is through evaluation that students are rated as high quality or low quality. The university must ensure that there are measures (indicators) put in place to ensure that whatever tag of quality is placed on a product is commensurate with what the product gives in order for the society to gain confidence in the product. This is a task that must be done by the academic department because a system that does not assure quality of its product in a global market that is competitive, will eventually come to atrophy, (Ogbodo, Efanga \& Nwokomah, 2013). Assessment of learning practice motivates students to learn, improve their performance in English and allows them freedom and time to learn better and to become more responsible for their own learning (Abdul, 2018).

The purpose of teaching is to make students' learning possible. According to Green (2014) many lecturers in tertiary institutions face challenges when it comes to determining the aim and objectives of tertiary teaching. Our lecturer cannot teach ...." is a common thought which resonates in the minds of many undergraduate students when they sit in a classroom with a lecturer / instructor who is an expert in his or her discipline, but lacks experience or skills to engage students in the learning process (Riley \& Myers, 2014). Active and interactive classes are based on contemporary models, strategies and styles of learning in which quality of interpersonal relations of 
university teachers, assistants and students are deepened. The character of such teaching practice is based on contemporary paradigm of learning and teaching in which all participants learn from each other (Nedium, 2016). Interactive classes are based on defined goals and they are characterized, among other things, by a huge number of various teaching activities and methods.

Interactive lecturing can be interpreted in a number of different ways. For some, interactive lecturing involves a two-way interaction between the presenter and the participants. For others, it refers to increased discussion among the participants. Interaction can also refer to a student's involvement with the material or the content of a lecture; it does not necessarily mean that the audience has to do all of the talking. Interactive lecturing also implies a different way of approaching the teacher's role. In giving this type of presentation, the 'instructor frequently becomes a facilitator or coach', and more often than not, has to modify the lecture content to allow for discussion and to try new techniques. The National Literacy Strategy, England cited in Riley and Myers (2014), characterized teaching as interactive when students' contributions are encouraged, expected and extended to others. As such, in interactive classes, students' participation should be at a higher level of autonomy than that commonly found in the traditional initiation-responsefeedback approach. Interactions during lessons help in shifting the classroom from an environment in which students are totally dependent on the teacher to one in which students assume more responsibility for validating their own ideas. Wilen cited in Riley and Myers (2014) is of the view that effective use of discussions can impact positively on classroom management, especially for large groups. For teaching to be effective, it must involve a process of facilitating learning rather than simply transmitting knowledge from the teacher to the learner. As such, opportunities must be created to facilitate student-student and student-teacher interactions, self evaluation and inclusion of personal learning goals. Furthermore, adult learners should be allowed the opportunity to evaluate their own learning, concepts and ideas .This teaching method applies the strategies used by both teacher-centered and studentcentered approaches. The subject information produced by the learners is remembered better than the same information presented to the learners by the lecturer. The method encourages the students to search for relevant knowledge rather than the lecturer monopolizing the transmission of information to the learners. As such, research evidence on teaching approaches maintains that this teaching method is effective in improving students' academic performance. (Ganyaupfu, 2013). Nedium (2015) found out that interactive teaching stimulates creation of cooperative relations and contributes to dynamics of teaching process, motivates self activity initiative and active participation in students' involvement. 


\section{Statement of the Problem}

The quality of university education in Nigeria especially Delta State seems to be declining, and this seeming decline in quality in university education in recent years has received floods of criticism from stakeholders and society Okebukola, (2011). It appears the quality assurance mechanisms are no longer practiced by lecturers in the academic units. Graduates from these universities are deemed to be inferior when compared with those who studied in other universities in Nigeria. Some stakeholders have blamed the seeming low quality of graduates on the government. Conversely, the government has blamed universities and their managers for the seeming low quality of graduates in these universities claiming that the internal quality assurance mechanisms are not been complied with, hence the seeming low quality that is often attributed to universities in Delta State. This state of affairs has impacted negatively on graduates as many employers view them as unskilled and therefore unemployable. The perceived low rating of universities in Delta State is often blamed on the quality of graduates from the universities. The purpose of this study therefore is to assess the extent of lecturers' compliance with quality assurance mechanisms in public universities in Delta State.

\section{Aim and Objectives of the Study}

The aim of this study was to investigate lecturers' compliance with QAM in public universities in Delta State. Specifically, the objectives include to;

1. Determine the extent to which lecturers comply with measurement and evaluation of students learning outcome strategies in Public Universities in Delta State.

2. Ascertain the extent to which lecturers comply with the use of interactive teaching and learning method in Public Universities in Delta State.

\section{Research Questions}

1. What is the extent to which lecturers' comply with measurement and evaluation of students learning outcome strategies?

2. What is the extent to which lecturers make use of interactive teaching and learning method in the classroom?

\section{Hypotheses}

1. There is no significant difference between the mean rating scores of lecturers and students on the extent to which lecturers comply with measurement and evaluation of students learning outcome strategies in Public Universities in Delta State.

2. There is no significant difference between the mean rating scores of lecturers and students on the extent to which lecturers comply with the 
use of interactive teaching and learning methods in the classroom in Public Universities in Delta State.

\section{Methodology}

The descriptive survey research design was used to collect data from a large sample drawn from a population of 1,299 lecturers and 6,826 students. This design was used to describe the compliance of lecturers with quality assurance mechanisms with a focus on students learning outcome strategies and interactive teaching and learning in the classroom. A sample of 260 lecturers and 409 students representing $20.02 \%$ and $5.99 \%$ respectively of the population was used for the study, which was obtained using the proportionate random sampling technique. The instrument: a structured questionnaire was subjected to face and content validities. Three (3) senior lecturers in the Department of Educational Management and 2 lecturers from the Department of Psychology, Guidance \& Counseling, Measurement and Evaluation, validated the instrument. To establish the reliability of the instrument, copies of the instrument were administered to 20 lecturers who were not part of the sample but part of the population. The Cronbach Alpha was used to determine the internal consistency of the items. The reliability coefficients for the instrument were 0.76 and 0.97 , for section A and B respectively, while the overall reliability coefficient of the instrument was 0.88 , thus the instrument was considered good/reliable as recommended by Nunally and Bernstein (1994). Six hundred and sixty-nine (669) copies of the questionnaire were administered to the respondents by the researchers and two assistants; however, 628 copies were retrieved and used for computation. The research questions were analyzed using mean and standard deviation, while the hypotheses were tested using z-test.

\section{Results}

Research Question 1: What is the extent to which lecturers comply with measurement and evaluation of students learning outcome strategies as a quality assurance mechanism in public universities in Delta State? 
Table 1: Weighted Mean $(\bar{x})$, Standard Deviation (SD), mean of lecturers and students on the extent to which lecturers comply with measurement and evaluation of students learning outcome as a quality assurance mechanism in public universities in Delta State

\begin{tabular}{|c|c|c|c|c|c|c|c|c|}
\hline $\mathrm{S}$ & Compliance with measurement and & Lecturers & & Stude & & & Rank & Remark \\
\hline $\begin{array}{l}\text { l } \\
\mathrm{N}\end{array}$ & $\begin{array}{l}\text { evaluation of students learning } \\
\text { outcome strategies by lecturers }\end{array}$ & Mean $\bar{x}_{1}$ & SD & $\begin{array}{l}\text { Mea } \\
\mathrm{n} \overline{\mathrm{s}}_{2}\end{array}$ & SD & $\frac{\text { mean }}{\bar{s}_{1} \bar{x}_{2}}$ & & \\
\hline 1 & $\begin{array}{l}\text { Students are assessed with CA of } 30 \text { or } \\
40 \% \text { and examination of } 70 \text { or } 60 \%\end{array}$ & 3.55 & 0.75 & 3.44 & 0.74 & 3.49 & $3^{\text {rd }}$ & $\begin{array}{l}\text { High } \\
\text { Extent }\end{array}$ \\
\hline 2 & Students do not 'sort' lecturers. & 2.97 & 1.02 & 2.94 & 1.02 & 2.96 & 9th & $\begin{array}{l}\text { High } \\
\text { Extent }\end{array}$ \\
\hline 3 & $\begin{array}{l}\text { Students are assessed with end of } \\
\text { course (semester) examination. }\end{array}$ & 3.47 & 0.85 & 3.46 & 0.84 & 3.47 & 5 th & $\begin{array}{l}\text { High } \\
\text { Extent }\end{array}$ \\
\hline 4 & $\begin{array}{l}\text { Students are evaluated with } \\
\text { assignment. }\end{array}$ & 3.45 & 0.81 & 3.04 & 0.96 & 3.25 & $8^{\text {th }}$ & $\begin{array}{l}\text { High } \\
\text { Extent }\end{array}$ \\
\hline 5 & $\begin{array}{l}\text { Students are evaluated with term } \\
\text { paper. }\end{array}$ & 2.92 & 0.96 & 2.76 & 1.02 & 2.86 & $10^{\text {th }}$ & $\begin{array}{l}\text { High } \\
\text { Extent }\end{array}$ \\
\hline 6 & $\begin{array}{l}\text { Students' academic performances are } \\
\text { assessed with project work for } \\
\text { undergraduate and thesis for post } \\
\text { graduate. }\end{array}$ & 3.60 & 0.70 & 3.41 & 0.83 & 3.51 & $1^{\text {st }}$ & $\begin{array}{l}\text { High } \\
\text { Extent }\end{array}$ \\
\hline 7 & $\begin{array}{l}\text { Students are not allowed to engage in } \\
\text { exam malpractice. }\end{array}$ & 3.45 & 0.83 & 3.54 & 0.77 & 3.49 & $4^{\text {th }}$ & $\begin{array}{l}\text { High } \\
\text { Extent }\end{array}$ \\
\hline 8 & $\begin{array}{l}\text { Students sit properly during } \\
\text { examination. }\end{array}$ & 3.42 & 0.82 & 3.45 & 0.83 & 3.44 & $6^{\text {th }}$ & $\begin{array}{l}\text { High } \\
\text { Extent }\end{array}$ \\
\hline 9 & $\begin{array}{l}\text { Students are assessed with punctuality } \\
\text { and regular attendance to class. }\end{array}$ & 3.40 & 0.81 & 3.24 & 0.83 & 3.32 & $7^{\text {th }}$ & $\begin{array}{l}\text { High } \\
\text { Extent }\end{array}$ \\
\hline $\begin{array}{l}1 \\
0\end{array}$ & $\begin{array}{l}\text { Students are not allowed to take phone } \\
\text { or any item that can be used for exam } \\
\text { mal-practice into the examination hall. }\end{array}$ & 3.36 & 0.88 & 3.65 & 0.69 & 3.51 & $1 \mathrm{st}$ & $\begin{array}{l}\text { High } \\
\text { Extent }\end{array}$ \\
\hline & TOTAL & 3.36 & 0.84 & 3.29 & 0.85 & & & \\
\hline
\end{tabular}

The result in Table 1 revealed the mean scores and standard deviation of students and lecturers on items 1-10. The mean scores for lecturers ranged between 2.92 and 3.60, and the mean score for students is between 2.76 and 3.65 , furthermore, the grand mean is 3.36 for lecturers and 3.29 for students, judging by the data obtained, the extent to which lecturers in public universities in Delta state complied with measurement and evaluation of students learning outcome strategies is high. This is because the mean score of the items for lecturers and students obtained is above the criterion mean of 2.50. Items $1-10$ is ranked $3^{\text {rd }}, 9$ th, 5 th, 8 th, 10 th $, 1^{\text {st }}, 4$ th, 6 th, 7 th, $1^{\text {st }}$ respectively. Therefore, the extent lecturers complied with measurement and evaluation of students learning outcome in public universities in Delta State is high.

Research Question 2: What is the extent to which lecturers comply with the use of interactive teaching and learning methods in the classroom? 
Table 2: Weighted Mean $(\bar{x})$, Standard Deviation $(S D)$, mean of lecturers and students on the extent to which lecturers comply with the use of interactive teaching and learning as a quality assurance mechanism in public universities in Delta State

\begin{tabular}{|c|c|c|c|c|c|c|c|c|}
\hline $\begin{array}{l}\mathrm{S} / \\
\mathrm{N}\end{array}$ & $\begin{array}{l}\text { Compliance with the use of interactive } \\
\text { teaching and learning method }\end{array}$ & $\begin{array}{l}\text { Lectur } \\
\text { Mean } \\
\bar{s}_{1}\end{array}$ & SD & $\begin{array}{l}\text { Students } \\
\text { Mean } \bar{x}_{2}\end{array}$ & SD & $\begin{array}{l}\text { Av } \\
\text { mean } \\
\bar{s}_{1} \bar{x}_{2}\end{array}$ & Rank & Remark \\
\hline 11 & $\begin{array}{l}\text { Lecturers facilitate discussion in the } \\
\text { classroom }\end{array}$ & 3.44 & $\begin{array}{l}0.7 \\
9\end{array}$ & 3.07 & 0.74 & 3.49 & $2^{\text {nd }}$ & $\begin{array}{l}\text { High } \\
\text { Extent }\end{array}$ \\
\hline 12 & $\begin{array}{l}\text { Lecturers encourage peer teaching by } \\
\text { grouping the students and appointing a } \\
\text { brilliant student to lead each group }\end{array}$ & 2.87 & $\begin{array}{l}0.9 \\
3\end{array}$ & 2.52 & 1.02 & 2.96 & $10^{\text {th }}$ & $\begin{array}{l}\text { High } \\
\text { Extent }\end{array}$ \\
\hline 13 & $\begin{array}{l}\text { Lecturers encourage sharing of ideas } \\
\text { among students }\end{array}$ & 3.32 & $\begin{array}{l}0.8 \\
4\end{array}$ & 2.97 & 0.84 & 3.47 & $3^{\text {rd }}$ & $\begin{array}{l}\text { High } \\
\text { Extent }\end{array}$ \\
\hline 14 & $\begin{array}{l}\text { Lecturers encourage } \\
\text { interaction }\end{array}$ & 3.32 & $\begin{array}{l}0.8 \\
4\end{array}$ & 2.83 & 0.96 & 3.25 & $5^{\text {th }}$ & $\begin{array}{l}\text { High } \\
\text { Extent }\end{array}$ \\
\hline 15 & $\begin{array}{l}\text { Lecturers employ feedback mechanism to } \\
\text { monitor learning-lecture response system }\end{array}$ & 3.21 & $\begin{array}{l}0.8 \\
7\end{array}$ & 2.94 & 1.02 & 2.86 & $5^{\text {th }}$ & $\begin{array}{l}\text { High } \\
\text { Extent }\end{array}$ \\
\hline 16 & $\begin{array}{l}\text { Lecturers allow students to monitor their } \\
\text { own learning by answers to questions in the } \\
\text { classroom }\end{array}$ & 3.18 & $\begin{array}{l}0.8 \\
4\end{array}$ & 2.98 & 0.83 & 3.51 & $5^{\text {th }}$ & $\begin{array}{l}\text { High } \\
\text { Extent }\end{array}$ \\
\hline 17 & $\begin{array}{l}\text { Lecturers allow students to set their own } \\
\text { learning objectives }\end{array}$ & 3.04 & $\begin{array}{l}0.8 \\
8\end{array}$ & 2.59 & 0.77 & 3.49 & $9^{\text {th }}$ & $\begin{array}{l}\text { High } \\
\text { Extent }\end{array}$ \\
\hline 18 & $\begin{array}{l}\text { Lecturers encourage students feedback to } \\
\text { improve students' work }\end{array}$ & 3.16 & $\begin{array}{l}0.8 \\
8\end{array}$ & 2.77 & 0.83 & 3.44 & $8^{\text {th }}$ & $\begin{array}{l}\text { High } \\
\text { Extent }\end{array}$ \\
\hline 19 & $\begin{array}{l}\text { Lecturers encourage questions from } \\
\text { students }\end{array}$ & 3.52 & $\begin{array}{l}0.7 \\
6\end{array}$ & 3.23 & 0.83 & 3.32 & $1^{\mathrm{st}}$ & $\begin{array}{l}\text { High } \\
\text { Extent }\end{array}$ \\
\hline 20 & $\begin{array}{l}\text { Lecturers make sure students take } \\
\text { responsibility by encouraging them to } \\
\text { bring additional knowledge to class and to } \\
\text { provide inputs on assignments }\end{array}$ & 3.38 & $\begin{array}{l}0.8 \\
7\end{array}$ & 2.88 & 0.69 & 3.51 & $4^{\text {th }}$ & $\begin{array}{l}\text { High } \\
\text { Extent }\end{array}$ \\
\hline & Total & 3.24 & $\begin{array}{l}0.8 \\
5\end{array}$ & 2.88 & 0.9 & & & \\
\hline
\end{tabular}

The result on table 2 shows the mean scores and standard deviation of students and lecturers on items 11-20. The mean scores for lecturers range between 2.87 and 3.52 and the mean scores for students range between 2.52 and 3.23. Furthermore, the grand mean score for lecturers is 3.24 and 2.88 for students, the mean scores obtained for lecturers and students revealed that the extent to which lecturers complied with the use of interactive teaching and learning methods in the classroom is high, this is because, the mean scores obtained for both lecturers and students is above the criterion mean of 2.50. Items 11-20 ranked 2 nd, 10th, $3^{\text {rd }}, 5$ th, 5th, 5th, 9th, 8 th, $1^{\text {st }}, 4$ th using the average mean respectively. Therefore, the extent of lecturers' compliance with interactive teaching and learning method as a quality assurance mechanism in public universities in Delta State is high.

\section{Hypotheses}

Hypothesis 1: There is no significant difference between the mean rating scores of lecturers and students on the extent to which lecturers comply with 
measurement and evaluation of students learning outcome as quality assurance mechanisms in public universities in Delta State.

Table 3: z-test analysis of difference between the mean score of lecturers and students on the extent to which lecturers comply with measurement and evaluation of students learning outcomes in public universities in Delta State.

\begin{tabular}{lcccccccc}
\hline & $\mathbf{N}$ & $\bar{x}$ & SD & df & z-cal & z-crit & $\begin{array}{l}\text { Level of } \\
\text { significance }\end{array}$ & Decision \\
\hline Lecturers & 238 & 3.36 & 0.84 & 626 & & & & Ho was \\
Students & 390 & 3.29 & 0.85 & & 1.01 & 1.960 & 0.05 & accepted \\
\hline
\end{tabular}

Table 3 shows that the z-calculated value is 1.01 which is less than the $\mathrm{z}$ critical value of 1.96 at 0.05 level of significance with degree of freedom 626, therefore, the hypothesis which states that there is no significant difference between the mean rating scores of lecturers and students on the extent to which lecturers comply with measurement and evaluation of students learning outcomes in public universities in Delta State is accepted.

Hypothesis 2: There is no significant difference between the mean rating score of lecturers and students on the extent to which lecturers comply with the use of interactive teaching and learning method as a quality assurance mechanism in public universities in Delta State.

Table 4: z-test analysis of difference between the mean score of lecturers and students on the extent to which lecturers comply with the use of interactive teaching and learning

\begin{tabular}{llllllllll}
\hline & $\mathbf{N}$ & $\bar{x}$ & SD & df & z-cal & z-crit & $\begin{array}{l}\text { Level of } \\
\text { significance }\end{array}$ & Decision \\
\hline Lecturers & 238 & 3.24 & 0.85 & 626 & & & & Rejected \\
Students & 390 & 2.88 & 0.9 & & 5.14 & 1.960 & 0.05 & \\
\hline
\end{tabular}

Table 4 shows that the $\mathrm{z}$-calculated value is 5.14 which is greater than the $\mathrm{z}$ critical value of 1.96 at 0.05 level of significance with degree of freedom of 626, therefore the hypothesis is rejected, which means that there is a significant difference between the mean rating scores of lecturers and students on the extent to which lecturers comply with the use of interactive teaching and learning method in the classroom in public universities in Delta State.

\section{Discussion of Findings}

The discussion of findings of this study is as presented as follows:

\section{Extent of Lecturers Compliance with Measurement and Evaluation of Students Learning Outcomes}

The findings revealed that lecturers' compliance with measurement and evaluation of students learning outcomes in public universities in Delta 
State is high. This therefore means that lecturers in public universities in Delta state adequately employ the strategies of measurement and evaluation of students learning outcomes as revealed in the high mean rating scores of the respondents on all the items assessed. The test of hypothesis revealed that there is no significant difference between the mean rating scores of lecturers and students on the extent to which lecturers comply with measurement and evaluation of students learning outcome strategies. The result of the findings is surprising because the researchers expected that lecturers would not be able to employ the measures for assessing the learning experiences of students because of excess workload and time constraint as some lecturers are said to consider the time spent on continuous assessment as a waste. Some lecturers are also accused of showing a lackadaisical attitude towards formative assessment of their students, and lack of quality culture said to be prevalent in Universities in Delta State. The reason for this finding may be that the universities management has put in place certain measures to ensure that lecturers comply with appropriate measurement and evaluation of students learning outcome strategies, for evaluating students learning outcomes of which defaulters are penalized. It may also be that the university management has organized or sponsored lecturers to attend seminars and workshops where they have been taught the skills in test construction, utilization and administering of continuous assessment. Lecturers may also have fully appreciated the philosophy and strategies of continuous assessment as the way to go and so they do not consider time spent on continuous assessment as time wasted. This finding may also be due to orientation given to lecturers on the importance of evaluation on the quality of graduates, productivity of lecturers and reputation of their university. This finding is in tandem with the findings of Akpotu and Ikpesu (2014) who found that measurement and evaluation of students learning helps to strengthen the certification process of graduates from universities. In the same manner, this study is in agreement with Khondkar, Ahmadi, and Yousaf (2017) who found out that a collective assessment format allows students to be effective in demonstrating their knowledge. In the same vein the finding is in agreement with Abdul, (2018) who found out that assessment of learning practice motivates students to learn, helps them to improve their performance in English Language and allows them freedom and time to learn better and to become more responsible for their own learning. The findings of Ajuonuma (2007) that evaluation of students learning experience in Nigerian universities is made up of continuous assessment and end of semester examination in the three educational domains which account for $30 \% \mathrm{CA}$ and $70 \%$ examination respectively agrees with this finding. However, in a study carried out by Ofejebe, Nwogbo and Anachuna (2015), it was found that students learning experiences is carried out mainly 
in the cognitive domain at the detriment of other domains (Affective and Psychomotor) of learning.

\section{Extent of Lecturers Compliance with the use of Interactive Teaching and Learning Method}

The result showed that the extent of compliance of lecturers in public universities in Delta State in the use of interactive teaching and learning methods in the classroom is high; this implies that lecturers in public universities in Delta State adequately make use of interactive teaching and learning strategies in the classroom. The test of hypothesis revealed that there is a significant difference between the mean rating scores of lecturers and students on the extent to which lecturers comply with the use of interactive teaching and learning methods in the classroom in public universities in Delta State. This finding is surprising because many stakeholders outside the universities assume that lecturers use the traditional teaching method which is lecturing but the findings of the study revealed that the reverse was the case. The reason maybe that lecturers in public universities in Delta State are aware that interactive teaching and learning methods enable students participate actively in the teaching learning process. Also the university management may have encouraged lecturers to make use of interactive teaching and learning method in the classroom through workshops and seminars. Moreover, lecturers in public universities in Delta State may have discovered that this method of teaching makes learning more impactful and leads to development of quality skills and abilities. This finding is in line with Riley and Myers (2014) who found out that interactive teaching strategy creates opportunities for students to explore ideas, develop critical thinking skills, discuss societal issues and problems and engage in group decision and problem solving abilities, all of which are achieved through discussions. In the same manner, this finding is also supported by Nedium (2015) who found out that interactive teaching stimulates creation of cooperative relations and contributes to dynamics of teaching process, motivates self-activity and initiative, active participation and students' involvement. Ganyaupfu's (2013) study which found out that the use of both teacher-centered and student-centered teaching methods are the most effective methods that produce best results and, that subject information produced by the learners is remembered better than the same information presented to the learners by the lecturer. Furthermore, this finding is in agreement with Riley and Myers (2014), who also found out that the effective use of discussion, can impact positively on classroom management, especially for large groups. 


\section{Conclusion}

Based on the findings it was concluded that lecturers' compliance with measurement and evaluation of students learning outcome and the use of interactive teaching and learning methods in the classroom in public universities in Delta State is high. There is no significant difference between the mean rating scores of lecturers and students on the extent to which lecturers comply with student learning outcome strategies. There is a significant difference between the mean rating scores of lecturers and students on the extent to which lecturers comply with the use of interactive teaching and learning methods in the classroom.

\section{Recommendations}

1. The university management should formulate a policy that will make lecturers sustain the strategies of assessing the learning outcome of students.

2. University management should organize more lectures and seminars on how lecturers can sustain the strategies in the use of interactive teaching and learning methods in the classroom.

\section{References:}

1. Abdul, A.U.(2018). The impact of assessment for learning on students achievement in English for specific purposes. A case study of premedical students at Khartoum University Sudan: Canadian Center of Science and Education, 11(2).

2. Ajadi, T.O. (2010). Private Universities in Nigeria - The Challenges Ahead. American Journal of Scientific Research, 7:15-24.

3. Ajayi, I.A. and Ekundayo, H.T. (2008). Deregulation of University Education in Nigeria. Nebula 5.4. December, 2018

4. Ajuonuma, J.O.(2007). Strategies for quality assurance in the assessment of students' academic performance in Nigerian Universities in J.B. Babalola, G.O Akpa , A.OAyeni\& S.O Adedeji (Eds). Acess, Equity and Quality in Higher Education(255-262). Lagos. Awemark Industrial Printers.

5. Akpotu, C. \&Ikpesu, O.C. (2014).Quality assurance mechanism as means for improving certification of output in universities in Niger Delta States. Journal of Education and Practice.5(33)128-134

6. Ciwar, A. M. (2005). Teachers registration council of Nigeria and quality assurance in teacher education. Being a Lead Paper Presented at the Committee of Deans of Education in Nigeria Universities 2005 meeting University of Illorin.

7. Dimson, J.K. (2007). Assuring quality in assessment of students learning in the University in Babalola, J.B., Akpa, G.O., Ayeni, A.O. 
\&Adedeji, S.O. (Eds).Access, equity and quality in higher education (263-269). Lagos Awemark Publications.

8. Emetarom, U.G (2007) Student - Evaluation of teaching, an administrative strategy for quality assurance in tertiary institution in Nigeria inBabalola, J.B., Akpa, G.O., Ayeni, A.O. \&Adedeji, S.O. (Eds). Access, equity and quality in higher education (317 -325). Lagos Awemark Publications.

9. Enemali, I.A. \& Adah, O.C. (2015).Quality Assurance in Educational Administration in the Teaching of Farm Mathematics for National Integration in Nigeria. Journal of Education and Practice.6(23)52-56.

10. FRN (2009). National Policy on Education. Lagos. NERDC Press.

11. Ganyaupfu, E.M. (2013). Teaching methods and students' academic performance. International Journal of Humanities and Social Science Invention. 2 (9) 29-35

12. Green, P. (2014). Measuring service quality in higher education. A South African Case Study. Journal of International Education Research, 10(2); 131-1 42.

13. Jabbarifar, T. (2009). The importance of classroom assessment and evaluation in educational system (Proceedings of the 2nd International Conference of Teaching \& Learning (2009) INT University College Malaysia.

14. Khondkar, I., Ahmadi,P, \&Yousaf, S. (2017). Assessment format and students learning performance.https://arxiv.org/ftp/.

15. Malapati, A. \& Murthy, N.B.(2013). Performance of students across assessment method and courses using correlation analysis. Paper presented at the Innovation and Technology in Education (MITE), 2013, IEEE. International Conference in MOOC.

16. Mbakwem, J.N. \& Okeke, F.N. (2007).Enhancing internal and external quality assurance: Mechanisms in Nigeria universities through ICT compliance in Babalola, J.B., Akpa, G.O., Ayeni, A.O. \&Adedeji, S.O. (Eds).Access, equity and quality in higher education (307-315). Lagos Awemark Publications

17. Nedium, C. (2015). Interactive teaching as innovation in quality of didactical methodical organization of academic teaching. http://hrcak.srce.hr, 11(1) 76-91.

18. Nunally, J.C. \&Bernstein, I.H. (1994).Psychometric Theory ( $3^{\text {rd }}$ ed). New York: Mc Graw-Hill

19. Nzegbulem, P.S.C. \& Anyaegu, R.O. (2016). Supervision and Inspection for Quality Assurance and Control in Education. In Samuel O. Oluwuo, Victoria C. Onyeike, Juliana D. Asodike (Eds) Supervision and Inspection in Schools for Productivity. 
20. Odebiyi, A.I, \&Aina, O. I. (2009). Alternative modes of financing higher education in Nigeria and implication for university governance. Find Report. Accra: Association of African Universities. Retrieved from htt://www.aau.org/studyprogram/notpub/odebaina.pdf.

21. Ofojebe, W.N. Nwogbo, V.N. \&Anachuna, O.N. (2015). Comparative analysis of the use of internal measures for quality assurance in public and private universities in South East Nigeria.European Scientific Journal Edition, 11(7)110-135

22. Ogbodo, C.M., Efanga, S.I., \& Nwokomah, J.M. (2013).Strengthening The Internal Quality Assurance Mechanisms In The University. Academic Research International, 4(3).

23. Okebukola, p. (2011). Entrepreneurship in University Education: Beyond Talk. $27^{\text {th }}$ Convocation Lecture, University of Port-Harcourt, June $16^{\text {th }}$.

24. Okoche, J.M.M. (2017). Internal quality assurance in public and private universities in Africa; Dynamics; challenges and strategies. European Journal of Economic and Financial Research. http://oapub.org.

25. Okojie, J. (2013). Quality Assurance and the Challenges of Mandate Delivery in Nigerian Universities. Lecture Delivered at the $18^{\text {th }}$ Convocation Ceremony of Lagos State University, Lagos, February $19^{\text {th }}$.

26. Olatunbosun, J.B. (2007). The need for quality assurance in university education in Nigeria in Babalola,J.B., Akpan, G.O., Ayeni, A.O.\&Adedeji, S.O (Eds.), Access, equity and quality in higher education ( 335- 341).Lagos Awemark Publications.

27. Riley, C.K \& Myers B.D (2014). Incorporating interactive teaching approaches in the tertiary science classroom; benefits, challenges and deterrants to use in a Jamaican University. Science Journal of Education 2(5): 146-151. 